\title{
Implementation of Project Based Learning Method with Speech Analyzer App for Oninron Course
}

\author{
Dini Maulia ${ }^{1, *}$ Darni Enzimar Putri ${ }^{2}$, Rahtu Nila Sepni ${ }^{3}$ \\ ${ }^{1}$ Faculty of Humaniora, Andalas University, Padang \\ ${ }^{2}$ Faculty of Humaniora, Andalas University, Padang \\ ${ }^{3}$ Faculty of Humaniora, Andalas University, Padang \\ *Corresponding author.Email: dinimulia@hum.unand.ac.id
}

\begin{abstract}
Oninron Subject is compulsory for second-semester university students majoring in Japanese language and literature at Andalas University. This subject is categorized as specific linguistic course that discusses the theory of sound in language. This paper focuses on the implementation of Project Based Learning Method together with Speech Analyzer app. The project that is assigned to the students is to make their pocket dictionaries in which the words are taken from the Anime as the major source; later, the Japanese words are collected and arranged as dictionaries. It can be assumed that PjBL method is suitable for Oninron course as it is seen on the final mark that the students get in which A straight score as highest possible mark dominates the ratio. This PjBL learning method is responded by the students positively, it is indicated from the Google form questionnaires which indicate that students are highly interested in $\mathrm{PjBL}$ method for Oninron course.
\end{abstract}

Keywords: Learning method, Project Based Learning, Oninron, Speech Analyze

\section{INTRODUCTION}

Oninron subject 音 韻 論 (JPG 228) is a compulsory course for second-semester university students in Japanese Department Andalas University. Oninron in Indonesian is understood as 'teori tentang bunyi' or theory of sound which is also known as phonology. This course is considered as one of the obligatory subjects in linguistic, as the purposes of this course are:

1. Improving student understanding of the theory of sound in linguistic

2. Working on student capability in recognizing speech organs in creating sound during in language process

3. Improving student competency in recognizing the characteristic of both vocal and consonant sound in Japanese

4. Escalating students ability in identifying the intonation, tone, stress, and duration in Japanese pronunciation

5. Working on student capability in pronouncing sounds in Japanese correctly

Oninron course is not only focusing on improving student competency within the linguistic realm, but it also supports their capability in pronouncing the Japanese words and sound correctly. It also supports other skill courses in Japanese Department because the learning outcomes of the Oninron course are including

1. Students understand the theory of sound in linguistic

2. Students know the speech organs and how these organs can pronounce sounds

3. Students recognize the characteristic of both consonant and vocal sounds in Japanese

4. Students can identify the intonation, tone, stress, and duration in Japanese pronunciation

5. Students can pronounce sounds in Japanese correctly

Previously, Oninron course was conducted through TCL (Teacher centered Learning) method. Students were given the references in form of textbooks that would be used for one semester. During classes, lecturer delivered the course themes orally trough one-way communication; while the textbook that was used for the classes is a general linguistic book that focuses on the theory of sounds.

TCL method was not qualified in fulfilling the standard achievements of Oninron course, because students only learned the theory of sounds without analyzing the sound directly. Student failed to complete two major achievements for the course especially the part where students need to be able in identifying the intonation, tone, stress, and duration as well as capable in pronouncing Japanese sound correctly. It was almost impossible for the students to pronounce the words correctly because students need references from native speakers of Japanese to correct their pronunciation. While reading description of the theory without direct exposure to the language hinders student competency in imitating the sounds correctly. This problem can only be fixed with the presence of Japanese native speakers who also understand the theory of sound in linguistic. However, to provide native speakers has become the major obstacle so far; and to resolve this problem, Project Based Learning method with Speech Analyzer approach is applied. The students are assigned to complete a project where they identify the Japanese sounds trough apps 
which is then later arranged into their dictionaries. Project Based Learning which will be addressed as $\mathrm{PjBL}$ is a comprehensive learning approach involving active participation among students, it is more organized and cooperative in both investigating and resolving the problems (Musa, Faridah, dkk:2011). this paper will discuss the implementation of Project Based Learning method with Speech Analyzer apps for Oninron course.

\section{METHOD}

\subsection{Subject of Research}

The subjects of the research are second-semester university students batch 2019 majoring in Japanese language and literature at Andalas University. This research tries to measure students' progress through the implementation of Project Based Learning with Speech Analyzer apps for Oninron course.

\subsection{Time and Length of Research}

This research was conducted for six months from February and July 2020 during the second semester as the course is available.

\subsection{Place for Research}

It is classroom action research as the lecturers are also the researchers who monitor the execution of Oninron class with Project Based Learning method with Speech Analyzer app as an instrument. The course is split into 16 meetings that were mostly done within the classroom at Andalas University campus, Padang, West Sumatra, Indonesia.

\subsection{Research Procedure}

\subsubsection{Plan}

$\mathrm{PjBL}$ method is a learning model that is centralized on students; although it is common among natural science class, it also indicates that $\mathrm{PjBL}$ is also suitable for language concentration class (Poonpon, Kornwipa:2011). Tims dan Rodrigues (2009) had previously succeeded in applying PjBL among students who studied English as second language. The respondents for his research were adult students, and his result showed that PjBL could improve students' language skills through their personal experience in completing the project.

Fragoulis, and friends (2009) applied the PjBL for elementary school students in Greek who learn English. $\mathrm{He}$ found out that $\mathrm{PjBL}$ is effective to be implemented for language learning such as English and any other foreign language. Other researches also indicating that $\mathrm{PjBL}$ is also suitable for language learning especially foreign language. In Oninron course, $\mathrm{PjBL}$ method is done by assigning students with a project where they must identify the Japanese sound trough Speech Analyzer apps. This apps is an instrument to measure the language sounds to detect the intonation, tone, stress, and duration of the sound.

Since the learning method is different from what was previously done, so RPS or Semester Learning Plan should also be adapted. In RPS, student contracts and distinct learning methods for Oninron course in one semester are explained. If the class is previously conducted with TCL method, student projects are mostly in form of discussion. Currently, Oninron class is done in 2 discussion phrases, including theory discussion and project discussion. Theory discussion is done through group presentation as they are given with themes to be discussed during class meetings. The themes for the presentation are phonology theories as well as general knowledge that are needed for the project. Later, project discussion is done when the students have completed their mid-semester test, the discussion should be reported every week to track down their project completion.

\subsubsection{Learning Technology}

Speech Analyzer app has been used as the main instrument in recent language research. Putra dan Suparwa (2018) previously conducted a research Kaidah Struktur Frasa dalam Bahasa Melayu dan Indonesia using Speech Analyzer app to separate the data. Erawati (2017) in her Interpretasi Segmen Bunyi Bahasa Jawa Kuno: Analisis Speech Analyzer dan Fitur Distingtif writing also used Speech Analyzer app in analyzing sound change and transformation

in spectrogram. Lubis, and friends (2017) in his Bioacustic Analysis By Using Spektogram Speech Analyzer to Verify The Verbal Competence of Down Syndrome in Different Age: The Case Study of Peli and Sutan in SLB Negeri 1 Padang (A Neurolinguistic Review) used Speech Analyzer app to observe sound change in language that is produced by down syndrome patients.

Previous researches indicate that Speech Analyzer apps are often used in research that focuses on sound change in language. While the use of Speech Analyzer app for Oninron course is crucial as the instrument to analyze the sound to complete their project. The project that is given to the students is designed to help them explore the form of sound in Japanese, in which the sounds are taken from Anime that used Japanese for communication. Students can choose their Anime as the source of data, they later put the single words within the Anime together and then identify each sound. The collection of words are later transcribed, interpreted, and arranged into pocket dictionaries. The dictionaries include information of words, description, sounds in phonetic symbols; the dictionaries are used as their words bank that is valuable for their research writing. 


\subsubsection{Observation}

Group discussion is done ten times; during this time, students are expected to start translating the Anime that is chosen as the main source of data. Trough group presentation, students will also learn the theory of sound in Japanese. The theory is in parallel with the data that are found, so it can be used to help the students in improving their Japanese skills especially in correcting their pronunciation to be precise as the native speaker. Moreover, students are free to ask lecturer for consultation during group discussion phase. Later, students are given three weeks to understand the use of Speech Analyzer app as their main instruments for the project, the theories that were given during group discussion will be practiced with the help of the app; it is then categorized as project discussion. Through this phase, students are required to inform their project progress every week. Lecturer's major task during this phase is observing the students' understanding and capability in separating Japanese sounds trough Speech Analyzer apps.

\subsubsection{Evaluation}

Learning evaluation is done in writing as part of Mid Semester Test after completing group discussion phase. At least 10 themes that are discussed during group discussion are then tested during Mid Semester Examination as part of learning evaluation. The pocket dictionaries that are completed by the student should be submitted at final test, in which the project is classified as an unwritten evaluation. In collecting the words in form of pocket dictionary, students will be able in improving their understanding about the theories that have been discussed during group discussion, they can also improve their Japanese vocabularies which is crucial for this project, students can classify the Japanese words as they are different in forms. As a result, marking the project is also part of learning evaluation for Oninron course.

\section{RESULT AND DISCUSSION}

\subsection{Learning Process}

Oninron learning is conducted with Project Based Learning method as the student is assigned to complete a group project to write their own pocket Japanese Indonesia dictionary which will be collected at the end of the semester. The dictionary is written based on the movie that uses Japanese as communication, so students will collect the words from the movie that is chosen. In week I, the lecturer explains the RPS and student contract for Oninron course. Students are also informed that the class will be supervised by three different lecturers, each lecturer will contribute 5 meetings in one semester, and it should also be noted that only the first meeting where the oral lecturer is held. The class is divided into two groups that are theory and project discussion group. 10 group for theory discussion is formed to present their themes in which each group consist of 3 to 4 students. Overall, 4 project discussion groups are formed, each group has 10 members. The project discussion group is larger than the theory discussion group because the project is arduous, but the student can choose their source and reference for collecting the words for the dictionary project. The anime that they choose is decided after week one. At least 8 anime that are used by the student to build their pocket dictionaries with entitle:

Danshi Koukousei ni Nichijou, duration 48 minutes Nanatsu no Taizai Torawari Tenkubito, duration 1 hour 34 minutes

Yuru Camp, duration 30 minutes Kimetsu no Yaiba, duration 48 minutes Boruto The Movie, duration 60 minutes Kanata no Asutora, duration 48 minutes

K-On Movie Trip to London, duration 1 hour 20 minutes

Re:zero kara Hajimaru Seikatsu, duration 50 minutes These Anime are chosen based on group project discussion, and these titles should be collected to the supervisor in week two, it can be said that student has started their project in collecting the words since week two after they decide the title of the anime that they choose.

In week II until week XI, theory discussion is also conducted as there are 10 themes that relevant to the concept, theory, analysis correspond to Oninron course that should be presented by the students in front of the class. Themes and theories have been written in RPS which is explained and delivered to the students at first meeting. Students present the themes every week based on the schedule that has been written in RPS. Mid Semester Test is not done based on the schedule; instead, it is postponed until week XII, because 10 themes should be completed first during theory discussion before evaluation is possible. The following week after Mid Semester test which is week XIII until XV, students will be introduced with Speech Analyzer apps. Through these meetings, students also need to report the progress of their group project before collecting their final work at Final Exam.

Throughout project discussion, students can report their difficulties in completing the project, Whatsapp group that consists of lecturers and group leaders are also available for project discussion and sharing information. Problems that are risen during the project will be discussed with the lecturers as supervisors who will also offer possible solutions.

\subsection{Learning Outcome}

$\mathrm{PjBL}$ is a collaborative method that relies on active autonomous participation from the student to meet the academic achievement that can be get through structured investigation and direct practice (Kokotsaki, dkk:2016). 
from the implementation of PjBL method, it can be concluded that this method is suitable for Oninron course because it can cover the 2 learning outcomes that are impossible trough to TCL method, those academic achievements include identifying the intonation, tone, stress, and duration as well as capable in pronouncing Japanese sound correctly. This method is preferable because students hardly have chance to meet Japanese native speakers to practice their language. The project will allow students to listen to the Japanese words directly from the Anime while the Speech Analyzer apps will allow the students to investigate and explore the sounds in Japanese in detail. Speech Analyzer apps are equipped with programs that can unravel sound into intonation, stress, tone, and duration. In other words, this app will help students in measuring the high and low tone as well as long and short duration in detail.

The student will split the sound if they can't identify the language after hearing them for a couple of times. The splitting of sound is detected trough the apps to match the sound in the anime. The words are collected and written down into a pocket dictionary, the words that need to be written is singular vocabulary as noun, verb, and adjective. Other words classification is not included in this dictionary, because Oninron course is taken by university students in their second semester who are still on the elementary level in understanding Japanese language. When collecting the data, students will find out that most of the words have transformed or changed and they are mostly not in singular form, so they must change those words into singular form before writing them down into the dictionary. Words transformation is common in Japanese especially in verb, adjective, and noun which is the reason why these words classification are chosen for this project. Trough collecting the word into dictionary, students will also improve the Japanese skill especially understanding the word transformation form in Japanese.

As the sound in Japanese has been clearly defined, the student can also practice their pronunciation trough the apps. Students are required to take pronunciation. Accuracy tests individually trough wave measurement system on Speech Analyzer apps. Students' voices will be recorded, detected, and compared in terms of intonation, tone, stress, and duration of the native Japanese pronunciation. As a result, students will recognize their mistakes and imitate the sound correctly. It shows that $\mathrm{PjBL}$ is suitable for Oninron course, as it supports the entire academic achievements that are previously impossible with TCL method.

\subsection{The Distribution of Students' Score}

The success of PjBL in Oninron course can also be seen from the final score distribution among the students. The ratio of the final score with PJBL learning method compare to TCL method can be seen on the following table

Table 1: Score Distribution among Students Who Take Oninron Course in Second Semester 2018/2019

\begin{tabular}{|c|c|c|c|c|c|c|c|c|c|}
\hline $\begin{array}{c}\text { Score } \\
\text { distribution }\end{array}$ & $\mathrm{A}$ & $\mathrm{A}-$ & $\mathrm{B}+$ & $\mathrm{B}$ & $\mathrm{B}-$ & $\mathrm{C}+$ & $\mathrm{C}$ & $\mathrm{D}$ & $\mathrm{E}$ \\
\hline $\begin{array}{c}\text { Number of } \\
\text { students }\end{array}$ & 19 & 16 & 9 & 16 & 5 & 3 & 2 & 0 & 3 \\
\hline Percentage & $25.3 \%$ & $21.3 \%$ & $12 \%$ & $21.3 \%$ & $6.7 \%$ & $4 \%$ & $2.7 \%$ & $0 \%$ & $4 \%$ \\
\hline $\begin{array}{c}\text { Score } \\
\text { distribution }\end{array}$ & $\mathrm{A}$ & $\mathrm{A}-$ & $\mathrm{B}+$ & $\mathrm{B}$ & $\mathrm{B}-$ & $\mathrm{C}+$ & $\mathrm{C}$ & $\mathrm{D}$ & $\mathrm{E}$ \\
\hline $\begin{array}{c}\text { Number of } \\
\text { students }\end{array}$ & 8 & 12 & 12 & 21 & 7 & 1 & 1 & 0 & 1 \\
\hline Percentage & $12.6 \%$ & $19 \%$ & $19 \%$ & $33 \%$ & $11 \%$ & $1.5 \%$ & $1.5 \%$ & $0 \%$ & $1.5 \%$ \\
\hline
\end{tabular}

Table 2: Score Distribution among Students Who Take Oninron Course in Second Semester 2019/2020

Table 1 shows that the score distribution in Oninron course in the previous semester is dominated with $\mathrm{B}$ for $33 \%$, followed by $\mathrm{A}-$ and $\mathrm{B}+$ for $19 \%$. while students who got $\mathrm{A}$ is only for $12.6 \%$ with $\mathrm{C}$ and $\mathrm{E}$ students are $1.5 \%$., and no student was recorded to get $\mathrm{D}$ for the course. Compare to $\mathrm{PjBL}$ learning in table 2, the percentage of students who get $\mathrm{A}$ is $25.3 \%$. followed by $\mathrm{A}-$ and $\mathrm{B}$ for $21.3 \%$, while $\mathrm{B}+$ and $\mathrm{B}$ - are approximately $12 \%$ and $6.7 \%$, students with $\mathrm{C}+$ and $\mathrm{E}$ are estimated around $4 \%$, and $2.7 \%$ for $\mathrm{C}$ and no record for $\mathrm{D}$. in $2018 / 2019$ second semester, the number of students who take Oninron Course are 63 people while in 2019/2020 the number increases to 75 people.
After comparing both table 1 and table 2 it can be seen that $\mathrm{PjBL}$ for Oninron course is a success, as the percentage of students who get $\mathrm{A}$ on their final has increased. Also, it is noted the number of students who take the classes has increased from 63 to 75 people. Although the percentage of students who get $\mathrm{E}$ is also increased, this percentage is resulted by their indiscipline behavior as they attend less than $75 \%$ meetings. It is explained in student contract that those who have less than $75 \%$ attendance will automatically get $E$; this consequence has been explained and agreed during the first meeting. As consequence, these students are marked as $\mathrm{E}$ that makes the percentage for lowest score increased compare to the previous semester. 


\subsection{Students' Respond toward the Improvement in Learning Method}

Students highly regard the implementation of PjBL method for Oninron course. Through the questionnaire on Google form, students are required to comment on the advantage and disadvantage of PjBL method for Oninron classes, students noted that the advantage of this method include

1. Students are motivated to learn the correct Japanese pronunciation trough attractive media especially Anime

2. Students can understand the phonology transcription easily as writing their pocket dictionary require them to write phonology transcription

3. Students can improve their ability in detecting Japanese word transformation

4. Improving their Japanese vocabulary that rarely practiced in class

5. As an experience in writing their dictionary

Not only does the advantage of PjBL method that is become the focus of the students but also the disadvantages. These drawbacks of this method are triggered by the current pandemic situation that makes the course need to be held online after 11 weeks that makes group discussion can only be possible trough daring communication. Problems that are faced by students are:

1. Introduction to Speech Analyzer app as an instrument is not maximum, although the app itself is very helpful in completing the group project

2. Group coordination is hard to be done because group discussion can only be possible trough daring communication.

Although the problems that arise are mostly caused by the pandemic. However, the entire practice of $\mathrm{PjBL}$ is accepted by the students as it can be used as an alternative learning method for Oninron classes.

\section{CONCLUSION}

Oninron course is a compulsory subject for Japanese department students in their second semester of university. The academic achievements for this course are 1) understanding toward the theory of sound in linguistic 2) capability in recognizing speech organs in creating sound during in language process 3) competency in recognizing the characteristic of both vocal and consonant sound in Japanese

4) ability in identifying the intonation, tone, stress, and duration in Japanese pronunciation 5) Working up on student capability in pronouncing sounds in Japanese correctly. These academic achievements were previously impossible to pass when the previous TCL method was applied for the Oninron class. It is the reason why Project
Based Learning method with Speech Analyzer apps is introduced to replace the old learning method which is not effective.

$\mathrm{PjBL}$ learning method is divided into two phases, they are theory and project discussion. Groups are made for each phase in which the group from the first phase will be different from the second phase. In dividing the students, the group for the second phase which is also known for project discussion group will have greater members than the group in the first phase because the project needs more human source than theory discussion. For PjBL learning method, students are assigned to complete pocket dictionaries. The collected words are taken from the chosen anime as their major source. Trough completing the project, students need to use the Speech Analyzer app to detect the correct sound in Japanese.

$\mathrm{PjBL}$ method is a suitable learning method that can be implemented to Oninron course, it is shown from the questionnaire responses that are answered by the students as well as the final mark of each student. Compare to the previous year, the number of students who get straight $\mathrm{A}$ for the Oninron course has increased, and it is also students who get A that dominate the class with the highest percentage. Students also give positive responses toward PjBL learning method as it is shown on the answered questionnaire in Google form. The implementation of $\mathrm{PjBL}$ learning method has both advantages and disadvantages, the main advantages of this method include motivating students to learn the correct Japanese pronunciation, understanding the phonology transcription easily, improving their ability in detecting Japanese word transformation, improving their Japanese vocabulary, and gaining experience in writing their dictionary. These entire advantages of PjBL method become more interesting when the student can choose their favorite media such as Anime. Although PjBL method is proven to be effective and beneficial, there are still problems that are rises during the implementation. One of the drawbacks of the method is caused by COVID 19 pandemic that makes the learning system need to be changed, in which face to face meetings need to be replaced with online classes. As the result, students cannot understand how to use Speech Analyzer app thoroughly because they cannot discuss with their lecturer directly. Group coordination is also hard to be done because the entire system needs to be replaced with online communication.

\section{AUTHORS' CONTRIBUTIONS}

Author contribution to this article is not only as researchers but also as the supervisors for Oninron classes

\section{ACKNOWLEDGMENTS}

We adress gratitute to Lembaga Pengembangan, Pembelajaran, dan Penjaminan Mutu (LP3M) Universitas 
Andalas that has given us chance to complete as well as to fund the research of learning method for Oninron course. The entire funding for this research is supported by LP3M Universitas Andalas.

\section{REFERENCES}

[1] Erawati, N.K.R.. Interpretasi segmen bunyi bahasa jawa kuno: Analisis speech analyzer dan fitur distingtif. Jurnal Aksara, 29(2), 2017, pp.225-238.

[2] Fragoulis, I. and Tsiplakides, I.. Project-Based Learning in the Teaching of English as A Foreign Language in Greek Primary Schools: From Theory to Practice. English Language Teaching, 2(3), 2009, pp.113-119.

[3] Kokotsaki, D., Menzies, V. and Wiggins, A.,. Projectbased learning: A review of the literature. Improving schools, 19(3), 2016, pp.267-277. DOI: https://doi.org/10.1177/1365480216659733

[4] Lubis, dkk.. Bioacustic Analysis By Using Spektogram Speech Analyzer to Verify The Verbal Competence of Down Syndrome in Different Age: The Case Study of Peli and Sutan in SLB Negeri 1 Padang (A Neurolinguistic Review). Dipublikasikan dalam Proceeding 3 rd International Seminar on Linguistics (ISOL-3) Universitas Andalas, August 24, 2017.

[5] Musa, F., Mufti, N., Latiff, R.A. and Amin, M.M.,.Project-based learning: Promoting meaningful language learning for workplace skills. ProcediaSocial and Behavioral Sciences, 18, 2011, pp.187195.

DOI:https://doi.org/10.1016/j.sbspro.2011.05.027

[6] Poonpon, K.. Enhancing English skills through project-based learning. The English Teacher, 2017, p.1-10.

[7] Putra dan Suparwa. Kaidah Struktur Frasa dalam Bahasa Melayu dan Indonesia. Laporan Penelitian. Bali: Universitas Udayana. 2018

[8] Tims dan Rodrigues. Project Based Learning in Adult English as A Second Language ESL Programms Students' Perspectives. Disertasi. Mexico: New Mexico State University, 2009. 